\title{
STO LET LJUDSKIH VISOKIH ŠOL (VOLKSHOCHSCHULEN) V NEMČIJI
}

Razlogi za razvoj množičnega izobraževanja odraslih v Nemčiji so povezani z razvojem gospodarstva, veliko rastjo prebivalstva, urbanizacijo in novimi potrebami družbe. V 19. stoletju je bila Nemčija industrijsko razvita država. Zaradi velikega števila delavcev in potreb po njihovem izobraževanju so se v drugi polovici 19. stoletja okrepila delavska gibanja. Od leta 1865 dalje so se za izobraževanje delavcev vzpostavljale »delavske zveze« (Arbeiterverbände). To je bil začetek delavskega izobraževanja (»znanje je moč«), ki je služilo emancipaciji delavskega razreda (Nuissl in Pehl, 2004).

Med letoma 1892 in 1908 je bilo pomembno gibanje za ljudsko izobraževanje Nemcev, ki je spodbudilo nastanek prvih organiziranih ljudskih in potujočih knjižnic. V tem času je nastalo prek 4000 ljudskih in 1200 potujočih knjižnic (Picht, 1950). Vzporedno s tem so se v Nemčiji razvijala tudi izobraževalna društva. Leta 1871 je meščansko liberalno gibanje (Bürgerlich-liberale Bildungsbewegung) ustanovilo »Društvo za širjenje ljudske izobrazbe« (Gesellschaft für Verbreitung von Volksbildung) (Tippelt in von Hippel, 2011). To je dalo podlago za sistemsko izobraževanje odraslih, saj je bila v njegovem okviru leta 1879 v Berlinu ustanovljena prva ljudska visoka šola - Humboldtova visoka šola (Humboldt-Hochschule), leta 1920 pa je nastala berlinska ljudska visoka šola (Volkshochschule Gross-Berlin). Obe šoli sta poleg splošnega znanja prenašali tudi praktična strokovna znanja. Temeljna metoda izobraževanja odraslih je bilo občasno predavanje, temeljna oblika izobraževanja odraslih pa je bil tečaj, ob njem pa so bile še druge oblike, na primer delovne skupine in potovanja. To je bilo prvo uresničenje ideje danske ljudske visoke šole $\mathrm{v}$ Nemčiji, a v specifični obliki (večerna ljudska visoka šola brez danskega načina skupnega internatskega bivanja) (Hirsch, 1927). Leta 1893 so se pojavili popularni univerzitetni ekstenziji (University Extension; tečaji izrednega študija za odrasle po angleškem vzoru), najprej v Jeni, potem v Leipzigu in Münchnu (Picht, 1950).

Od leta 1909 naprej se je veliko razpravljalo o problemih izobraževanja odraslih in organiziranju šol za odrasle. V tem času je imelo poseben pomen delo Antona Heinricha Hollmanna Dansko izobraževanje odraslih, objavljeno leta 1909, ki se lahko šteje za vzorno knjigo, saj gre za prenos idej danske ljudske visoke šole (Folkehøjskole). Med pomembnimi posamezniki tistega časa, ki so se zavzemali za ustanovitev ljudskih visokih šol (Volkshochschule), je bil Wilhelm Rein (profesor pedagogike in izobraževalec odraslih), ki je objavljal ideje o ljudski visoki šoli za izobraževanje odraslih od leta 1890 dalje. Leta 1919 je bil eden od soustanoviteljev ljudske visoke šole v Thüringenu (Hinzen, 1999). 
Prve ljudske visoke šole v Münchnu (1896), Augsburgu (1904) in Bonnu (1904) ter tiste, ki niso bile vedno poimenovane $\mathrm{z}$ imenom »ljudska visoka šola«, imajo še daljšo tradicijo izobraževanja odraslih v Nemčiji, celo več kot sto let (Hinzen in Meilhammer, 2018). Glede na izobraževalno-vzgojno usmerjenost in organizacijo dela so delovale v dveh oblikah: domske ljudske visoke šole (Heimvolkshochschulen) in večerne ljudske visoke šole (Abendvolkshochschulen) (Hirsch, 1927). Domske ljudske visoke šole so bile vzpostavljene na podlagi danskih ljudskih visokih šol (Folkehøjskole) in so bile internatskega tipa z dvema semestroma letno ter so dajale splošno izobrazbo od 17 do 30 let starim osebam. V središču izobraževalno-vzgojnega procesa je bil nemški človek in njegova domovina, z zelo poudarjenim velikonemškim duhom. Izobraževali so se skupaj v instituciji kot ena velika nemška družina. Večerne ljudske visoke šole pa so nastale po zgledu angleških univerz (University Extension) in so bile samostojne andragoške ustanove. Čeprav so bile različne glede na pristop k izobraževanju, je bilo vsem skupno vzgojno-izobraževalno delo: politična in kulturna vprašanja, diskusije in razgovori, ciklusna predavanja, seminarji, tečaji z znanstvenih, kulturno-umetniških in tehničnih področij, študijska potovanja in razstave (Samolovčev, 1963).

Kot ustanovno leto za ljudske visoke šole (Volkshochschulen - VHS) v Nemčiji pa šteje leto 1919, ko so bile te prvič opredeljene kot državne ustanove za izobraževanje odraslih. To je spodbudilo širjenje mreže ljudskih visokih šol za izobraževanje odraslih, ki pa so se od prvih tovrstnih šol razlikovale tudi v sodobnem didaktičnem slogu, ki je pripadal »novi smeri«. To je bil prelomni čas, konec prve svetovne vojne, konec nemškega cesarstva, s tem pa tudi začetek želja po demokraciji. Tako je bila 9. novembra 1918 razglašena weimarska republika in s tem prvič vzpostavljena parlamentarna demokracija kot državna oblika na nemških tleh (Hinzen in Meilhammer, 2018). Dne 11. avgusta 1919 je bila sprejeta ustava weimarske republike, ki je v četrtem odstavku 148. člena imela zapisano odločilno zahtevo po razvoju in spodbujanju celotnega izobraževanja odraslih: »Država, dežele in lokalne skupnosti naj spodbujajo razvoj nacionalnega sistema izobraževanja, vključno z ljudskimi visokimi šolami.« (Hinzen, 1999, str. 32)

V obdobju weimarske republike je bilo izobraževanje odraslih državno priznano kot pomembno, vendar je bilo drugačno kot dotlej. V Nemčiji so takrat, kot omenja Buchwald (1925, v Hinzen in Meilhammer, 2018), doživljali duhovno-moralno krizo z izkušnjo razdvojenosti in osamljenosti. Zato ni naključje, da so prav v tem času pretresov ljudske visoke šole doživele velik razcvet. Začele so namreč služiti ljudem in demokraciji, ki je bila odvisna od ljudi (Buchwald, 1925, v Hinzen in Meilhammer, 2018). To je bila zlata doba $v$ razvoju nemške andragoške prakse.

Ljudske visoke šole so bile $\mathrm{v}$ obdobju weimarske republike dveh vrst: politično skrajno leve (npr. socialistično delavsko izobraževanje na ljudski visoki šoli v Tinzu) in desne izobraževalne ustanove (nacionalno konservativna ali nacionalno usmerjena ljudska visoka šola tudi za kmete) (Hinzen in Meilhammer, 2018).

Ljudske visoke šole so imele posebno javno poslanstvo, saj so bile od vseh institucij za izobraževanje odraslih odprte za vse ljudi, ki so se zavzemali za demokracijo v Nemčiji. 
Odrasli so se izobraževali o socialni in politični odgovornosti, hkrati pa se izobraževali tudi za poklic. Razvoj teh institucij je močno povezan s politično in družbeno zgodovino. To še posebej velja za obdobje nacionalsocializma (1933-1945) in čas delitve na Vzhodno in Zahodno Nemčijo po drugi svetovni vojni, ko je bila ideja o demokratičnem izobraževanju odraslih opuščena.

Ljudska visoka šola v nacionalsocialistični državi ni bila več svobodna in ideološko nevtralna ustanova ter se je preimenovala v nemško domovinsko šolo (Deutsche Heimatschule), ki je služila ciljem nacionalsocializma. Od leta 1949 do 1990 pa se pojavljata dva sistema ljudskih visokih šol za izobraževanje odraslih: zahodnonemški na stari organizacijski in idejni podlagi skandinavskega sistema izobraževanja odraslih in vzhodnonemški s posebno obliko sovjetskega sistema $\mathrm{z}$ močno poklicno usmerjenim izobraževanjem. Z nastankom združene Zvezne republike Nemčije leta 1990 so se ljudske visoke šole, ki so delovale po posameznih zveznih deželah Nemčije, organizirale v deželne zveze, ki so kasneje postale članice Zveze ljudskih visokih šol Nemčije (Deutschen Volkshochschul-Verband - DVV) (Hinzen in Meilhammer, 2018). DVV je predstavnica ljudskih visokih šol na zvezni, evropski in mednarodni ravni ter spodbuja nadaljnje izobraževanje odraslih. Je največja nemška krovna organizacija za 16 deželnih zvez ljudskih visokih šol in skoraj 900 ljudskih visokih šol v Nemčiji (Deutscher Volkshochschul-Verband, b.d.). Danes so ljudske visoke šole v Nemčiji v velikem razmahu, obstajajo $v$ mestih in na podeželju ter imajo različne programe za izobraževanje odraslih glede na njihove potrebe.

\section{Monika Govekar-Okoliš}

\section{LITERATURA}

Deutscher Volkshochschul-Verband. (b.d.). Pridobljeno s https://de.wikipedia.org/wiki/Deutscher_ Volkshochschul-Verband

Hinzen, H. (1999). Die Gründung von Volkshochschulen in Deutschland 1919 im Spiegel ihrer Festschriften zum 75-jährigen Bestehen. V W. Filla, E. Gruber in J. Jug (ur.), Erwachsenenbildung in der Zwischenkriegszeit (str. 28-44). Innsbruck-Wien: Studien Verlag.

Hinzen, H. in Meilhammer, E. (2018). 100 Jahre Volkshochschule - Einleitung zu diesem Heft. Bildung und Erziehung, 71(2), 125-136.

Hirsch, K. (1927). Die Humboldt-Hochschule, Freie Volkshochschule Gross-Berlin und die Volkshochschulfrage, Eine Studie über die Beziehungen zwischen Volkshochschule und Volkswirtschaft. Leipzig: Universitätverlag Noske.

Nuissl, E. in Pehl, K. (2004). Portrait of Continuing Education Germany. Bielefeld: W. Bertelsmann Verlag GmbH \& Co. KG.

Picht, W. (1950). Das Schicksal der Volksbildung in Deutschland. Braunschweig-Berlin-Hamburg: Georg Westermann Verlag.

Samolovčev, B. (1963). Obrazovanje odraslih u prošlosti i danas. Zagreb: Znanje.

Tippelt, R. in von Hippel, A. (2011). Einleitung. V R. Tippelt in A. von Hippel (ur.), Handbuch Erwachsenenbildung/Weiterbildung (str. 11-21). Wiesbaden: VS Verlag für Sozialwissenschaften. 